\title{
Geography and other Disciplines: Genealogy, Anamnesis, and the Canon
}

Andrew Barry, Department of Geography, UCL

\section{Abstract}

This article argues that the idea of the geographical canon has continuing value, although its constitution and scope need to be rethought. The argument draws on three sources of inspiration. One is the work of Quentin Skinner, who offered a critique of the idea of the canon of political thought before subsequently going on to act as the co-editor of a series of Texts in the History of Political Thought. The second is the method of genealogy, developed by Michel Foucault. Drawing on both the methodological writings of Foucault and their interpretation by Stuart Elden, I argue that the substance of a genealogy of geographical thought should not be confined to the work of geographers. The third inspiration for this article is the idea of anamnesis, introduced by the philosopher of science Isabelle Stengers in her study of the history of the physical sciences, Cosmopolitics. The practice of anamnesis, I argue, invites us to re-read texts that should continue to animate our thinking in the present. 
In an essay on "Meaning and Understanding in the History of Ideas' first published in 1969, the historian Quentin Skinner launched a sustained and influential attack against the idea of the canon in political thought. The notion of a canon, Skinner contended, implied that there were a number of 'classic texts' that contained 'dateless wisdom' and 'universal ideas.' Moreover, belief in the value of the canon had rested, he suggested, on a series of questionable pre-judgements 'about the defining characteristics of the discipline to which the writer is supposed to have contributed. ${ }^{11}$ In opposition to what he termed the 'mythology' of the canon, Skinner's counter-proposition was straightforward. Drawing inspiration from the historical method proposed by RG Collingwood and the philosophy of the later Wittgenstein and JL Austin, he urged historians of political thought to focus on the meaning and use that texts had at the time they were written. Rather than read classic texts in terms of their relation to so-called 'canonical doctrines', Skinner argued that texts should be read in relation to the specific questions and problems with which their authors and readers were concerned. ${ }^{2}$ In this light, the historian's dissatisfaction with what he took to be the then dominant approach to the interpretation of, for example, Descartes' Meditations 'stems from the fact that it leaves us without any sense of the specific question to which Descartes may have intended his doctrine of certainty as a solution. ${ }^{3}$ As Collingwood had argued, 'thinking is never done in vacuo: it is always done by a determinate person in a determinate situation. ${ }^{44}$

I begin by referring to Skinner's essay for two reasons. One is to recall that recent discussions about the value of a geographical canon come in the wake of a series of critiques of canonical thinking in other fields, including political theory. ${ }^{5}$ In this context, Skinner's intervention was but one of a series of critical accounts of the notion of the canon spread across the social sciences and humanities in the late twentieth century, drawing inspiration not just from the philosophy of Austin, Wittgenstein and Collingwood, but more broadly from a growing body of post-colonial, post-structuralist and feminist criticism. The idea of the canon, it was argued, not only led to the misinterpretation of texts, but was also associated with the exercise of power. As Charles Withers observes, 'even as some critics have defended the idea of a canon but recognised that the Western canon....has changed..., others have rejected such notions tout court, 
since there cannot ever be an agreed-upon measuring rod against which "good" canonical literature can be marked apart from the "bad". .6

A second reason for recalling Skinner's influential intervention is more surprising, and forms the heart of my argument. As we shall see, Skinner's work has not been associated with the rejection of the idea of the canon tout court, as one might expect from his 1969 essay, but with a development of a sense of an 'expanded' canon of political thought. In this paper I follow Skinner in rejecting the traditional idea of the canon, conceived as a given body of texts that defines the 'timeless essence' of a discipline, and instead endorse the idea of an expanded canon. The aim of the paper is both to clarify what kinds of texts might be included in an expanded canon of geographical thought, and to suggest why the existence of such a canon has some value. My proposition is that an expanded canon cannot and should not be confined to the discipline's 'classic texts'; rather, an expanded canon contains a shifting and necessarily contested body of work, including the work of authors and practitioners who are not typically thought to be geographers. ${ }^{7}$

The paper is organised in three parts. First, I discuss the idea of the expanded canon of political thought associated with Skinner's work as editor, together with the political philosopher Raymond Geuss, of the Cambridge Texts in the History of Political Thought. Despite my endorsement of the idea of an expanded canon, I depart from Skinner and Geuss's approach, while also observing significant differences between the teaching of politics and the teaching of geography. The second part the paper turns to consider how Foucault's genealogical method, which is often taken as the starting point for criticism of the traditional canon, ${ }^{8}$ may also suggest how the canon might be rethought and expanded. Here, I draw on Stuart Elden's recent critical reinterpretation of Foucault's lectures on governmentality and his The Birth of Territory. Elden's work, I argue, indicates the possibility of an expanded sense of the geographical canon that includes, amongst others, many of the authors contained in Skinner and Geuss's canon of political thought. In the third part of the paper I turn to the work of the philosopher Isabelle Stengers. Her anamnesis of the physical sciences, I argue, directs us to consider both the value of reading an expanded range of canonical texts and the importance of those disciplines, including geography, that give value to diverse forms of knowledge production, including field research. Stengers, like Foucault, views concepts not as abstract ideas, but as elements of what Foucault once termed 'an ensemble of practices'. ' While both authors 
implicitly reject the traditional understanding of the canon, their work shows us why the existence of an expanded canon should continue to matter.

\section{The Expanded Canon}

If Skinner's polemic is a reminder that debates about the value of the canon have been on going in a range of disciplines, it also directs us to an intriguing paradox. For Skinner himself, in his role as a series editor of the Cambridge Texts in the History of Political Thought went on to play an instrumental role in expanding the range of texts considered to be part of the canon. Far from destroying the canon of political thought, Skinner's intervention, along with others, appears to have generated the conditions for its progressive evolution and reinvigoration. Cambridge University Press makes its ambitions for the series clear:

Cambridge Texts in the History of Political Thought is now firmly established as the major textbook series in political theory in the anglophone world, with more than half a million copies distributed since its launch in 1988. The Cambridge Texts series presents to students all the core texts in the Western political tradition, from ancient Greece to the early twentieth century. All the familiar classic texts like Leviathan or The Prince have been or will be included, but much of the appeal of the series for teachers derives from its expansion of the traditional canon with a substantial range of less well-known works, many translated into modern English for the first time. ${ }^{10}$

This statement is not just an exercise in marketing; it also appears to reflect a shift in Skinner's own thinking over time. In a recent interview, in which he addressed the meaning and significance of his 1969 essay, he admitted that he was now 'ambivalent and perhaps confused' about the idea of the canon, acknowledging that he had become progressively less 'dogmatically reluctant' about the question since the publication of his original argument, and had come to recognise that 'leading thinkers have always attended to the work of other and earlier thinkers. ${ }^{11}$ Thus, while the older (pre-1969) understanding of the canon was clearly now untenable in his view, the notion of an 'expanded canon', promoted by Skinner and his co-editor, the philosopher Raymond Geuss, along with others in the Cambridge School, had acquired a new importance. In 
this revised account, 'a substantial range' of other texts formed part of the context that gave specific classical texts their meaning and significance. Notwithstanding the influence of Skinner's earlier essay, the reading of the canon has remained a core element of the undergraduate curriculum in political theory and philosophy.

Despite some differences, the broad terms of Skinner's original critique of canonical thought should be familiar to readers of the history of geography. Robert Mayhew, for example, echoed Skinner's argument in observing that earlier historians of geography have tended to project their particular account of the 'timeless essence' that defines the discipline: 'being timeless this essence is conflated with what geography has always been, and, switching from indicative to imperative, with what geography ought to be. ${ }^{12}$ Charles Withers has stressed the importance of a 'contextual reading of geography's canonical or classic texts. ${ }^{13}$ And in the introduction to The Geographical Tradition, David Livingstone rejected purely internalist approaches to reading historical texts, arguing, like Skinner, that the meaning and use of geographical knowledge had to be understood in its historical context. Such an approach, he contended, 'will enable us to work with a more realistic picture of geographical knowledge as a cultural product and a political resource. ${ }^{14}$ Livingstone's book included discussions of what we might call, following Geuss and Skinner, a 'substantial range of lesser-known works' in the history of geography, however, unlike the early Skinner, Livingstone recognised, following the hermeneutic philosophy of Hans-Georg Gadamer, that some form of pre-judice or prejudgement about the meaning of historical texts was inevitable. As Gadamer had understood, while contextual reading was necessary, the context that was taken to inform any reading could be never taken as settled. The problem for the historian, as Gadamer had argued, was to distinguish between a range of 'legitimate pre-judices' about both a text and its context, and the 'countless others' that were merely prejudices. ${ }^{15}$ In this account, the existence of a tradition was a pre-condition for interpretation, yet the tradition itself had to be continually re-interpreted.

While there are evident resonances between the work of historians of geography and historians of political thought such as Skinner, there are also differences between the pedagogic function of the 'canonical' texts of political thought and the canon of classic geographical texts. It is still the case that the undergraduate in politics or philosophy would be expected to read the work of, for example, Hobbes, Locke, Leibniz, Marx or 
Nietzsche, while few undergraduate geography students are likely to read, for example, Humboldt, Ritter, Reclus, Semple or Mackinder. Mayhew is surely right to argue that 'human geography is unusual in the extent and vigour of the community who, within the discipline, write histories of the discipline rather than leaving this to historians in a separate disciplinary context. ${ }^{, 16}$ Indeed, in a recent review, Felix Driver highlights the vitality of research on the history of geography in the UK in particular. ${ }^{17}$ Nonetheless, while there are no doubt variations in practice across different departments, the student of political thought, philosophy or sociology is likely to study a disciplinary 'canon' to an extent, or to a level, that the student of geography is not. ${ }^{18}$ There is no geographical equivalent of the Cambridge series of Texts in the History of Political Thought.

Of course there are a number of good reasons for the relative lack of interest in the geographical canon, when compared, for example, to the continuing interest in canonical political theorists and philosophers. First, many would argue that the writings of, say, nineteenth-century geographers are simply rather less intellectually significant than the work of nineteenth-century political thinkers and philosophers. In this light, some go as far to argue that reading the history of geography does not seem to be relevant to geographers, except to those who are also historians of geography. ${ }^{19}$ Secondly, through its association with empire, the history of geographical thought has come to be regarded as politically problematic in a way that, for example, the history of sociology has not. ${ }^{20}$ Thirdly, existing accounts of the history of geographical thought have tended to systematically exclude the work of women geographers, or refer to their contribution only fleetingly. As Avril Maddrell observes, 'through its inevitable selectivity, any canon reflects power, the power to include and exclude. ${ }^{21}$ Fourthly, the relative lack of concern with the 'geographical canon' might be considered one of the strengths rather than a weakness of geography today. Geographers have not been pulled down by the weight of tradition, because the tradition has little weight or coherence. If the idea of the canon implies regulation, then the regulatory authority of the geographical canon is now relativity limited. In these circumstances, lacking any unified sense of the value of a canon, geographers have been able to re-invent the discipline, drawing on diverse intellectual currents from beyond the discipline, although in doing so, according to John Agnew, geography has become 'particularly subject to what might be called "fanons": the tendency to lurch from one intellectual fashion to another without much attention to what came before. ${ }^{22}$ Fifthly, and perhaps relatedly, the discipline has arguably already 
become too fragmented, fractured into a series of distinct sub-fields, which are unlikely to be able to cohere around a single canon. ${ }^{23}$ In this light, although it may be useful for students of cultural geography to read Carl Sauer, for example, the search for a unified geographical canon is, in short, fruitless. ${ }^{24}$ Sixthly, any account of the history of geography would necessarily have to focus on a range of geographical practices surveying, mapping, teaching, exploring, fieldwork and so on - that may not so easily be captured in a series of canonical texts. Indeed, historians of geography have rightly drawn our attention to the critical importance of practices of exploration and fieldwork to the formation and transformation of the discipline across the course of the nineteenth and twentieth centuries. ${ }^{25}$

These are persuasive arguments. However, they leave open the question of how geographers should engage with the corpus of putative 'canonical' texts, in both teaching and research. Should the notion of a geographical canon be abandoned in the face of these difficulties, or sustained? My contention in this paper is that the idea of a geographical canon has continuing value, although its constitution and scope needs to be radically rethought, and its relation to contemporary politics explicitly addressed. In developing this argument, Skinner's work provides a helpful starting point. First, as his editorship of the Cambridge Texts in the History of Political Thought makes clear, the content of the canon could be expanded. After all, under the editorship of Geuss and Skinner the canon of political thought has come to include not just a range of previously untranslated texts in 'political thought', but also a series of authors who would not necessarily be located within the modern disciplines of politics. Thus the 'expanded canon' of political thought promoted by the Cambridge editors includes works by philosophers such as Locke, Hegel and Nietzsche, and sociologists such as Comte and Weber, as well as the geographer Peter Kropotkin. ${ }^{26}$ The limits of this canon are not defined by the apparent 'disciplinary' affiliation or identification of its authors, but by a broad and necessarily contested understanding of the scope of the field of politics and political thought.

\section{$\underline{\text { Genealogy and Politics }}$}

Although the publication of the Cambridge series expands the range of texts contained in the canon of political thought, it nonetheless has come to embody a quite traditional conception of the canon that revolves around the work of specific named authors and 
their contributions to the history of political ideas. In this respect, Foucault's genealogical method offers a clear challenge to the account of the Cambridge School of Skinner and Geuss. On the one hand, for Foucault, political thought is understood to be programmatic and technological as much as theoretical and discursive. This was made evident in Foucault's choice, in Discipline and Punish, to focus on Jeremy Bentham's account of the Panopticon rather than Bentham's explicit contributions to moral and political philosophy. ${ }^{27}$ As Foucault later observed, he was not engaged in examining 'more or less perfect forms of rationality but, rather, examining how forms of rationality inscribe themselves in practices or systems of practices. ${ }^{28}$ On the other hand, as Stuart Elden observes, '[genealogy] makes use of the textual and contextual accounts offered by Begriffsgeschichte [of Reinhard Kosseleck] or the Cambridge school but is critical of notions that the production of meaning is reliant on authorial intent. ${ }^{29}$ Nonetheless, as Elden's remarks suggest, there are some parallels between Foucault's and Skinner's approach to the history of concepts and, indeed, both Geuss and Skinner have commented on Foucault's work. ${ }^{30}$ Like Skinner, the genealogist is explicitly opposed to the idea that concepts have a timeless essence or a given meaning: '[genealogy] disturbs what was previously considered immobile; it fragments what was thought unified; it shows the heterogeneity of what was imagined consistent with itself. ${ }^{31}$ At the same time, Foucault contests the view that the evolution of concepts is the product of a single specific cause or a limited set of causes - an expression of particular institutional logics, paradigms, authorial intentions or economic conditions. Rather, the genealogist recognises that the history of concepts should be understood as an unfolding tradition, but the product of a 'multiplicity of conditions.' 32

In this context, Elden's own historical work is of interest, I argue, precisely because, like Skinner and Geuss, he suggests the possibility of an expanded canon, albeit one that is organised not around the work of canonical authors, but in relation to specific concepts and practices. ${ }^{33}$ This is particularly apparent in Elden's recent book, The Birth of Territory, in which he contends that the (limited) account of the history of the concept of territory given by Michel Foucault, primarily to be found in his lectures on 'Security, Territory, Population', is misleading. ${ }^{34}$ While this book is informed by Foucault's understanding of genealogy, Elden's project also draws in part on some of Foucault's specific observations on the history of political rationality. Elden elaborates, for example, on Foucault's brief observations on Leibniz ${ }^{35}$ in order to draw our attention to the critical historical 
importance of the philosopher as a theorist of the relation between sovereignty, territory and politics. In Elden's analysis, 'while it might appear that Hobbes's absolute sovereignty and Newton's absolute space define modern politics and geography, Leibniz's relational views of both are closer to how politics was actually practiced. ${ }^{36}$ Whereas the editor of a series of extracts of Leibniz's 'political writings' in the Cambridge Texts in the History of Political Thought has little to say about the philosopher's concern with the concept of territory, ${ }^{37}$ Elden re-reads the same texts as contributions to geographical, as well as political, thought.

In light of Elden's discussion of Leibniz, we can see how the scope of an expanded geographical canon might productively include a range of texts, including the work of Leibniz, which enter into the genealogy of geographical concepts. Just as it is necessary to turn to Leibniz, amongst others, to understand the transformation of the concept of territory and its political, economic and legal significance, so it would be necessary to consider the significance of a wide range of other writers and texts to trace the genealogy of such key geographical concepts as nature, environment, region, population, space, scale, landscape and place. ${ }^{38}$ Thomas Osborne and Nikolas Rose argue, following Foucault, that the history of 'social' thought is certainly not reducible to the work of sociologists. ${ }^{39}$ It includes the work of a diverse array of social reformers, doctors, statisticians, and intellectuals. Likewise, historians of geography have long recognised the ambiguous and contested boundaries of the discipline, and the critical importance in the development of the geographical thought of, for example, explorers, surveyors, geologists and naturalists, including, in particular, Charles Darwin. ${ }^{40}$ But in general, the genealogist of geographical concepts needs to be prepared to read the work of those who are not necessarily understood as geographers at all, including political theorists and philosophers. ${ }^{41}$ An expanded geographical canon need not be defined by the selfidentification of its authors, but the geographical problems and concepts with which they were concerned.

Genealogy, as Foucault made clear, is a political enterprise. It is intended to inform and transform our understanding of the present, interrogating and problematizing the significance of concepts that have become naturalised. ${ }^{42}$ Moreover, the genealogist does not treat concepts merely as concepts, but as political technologies, entangled in complex assemblages of relations: of discipline, government, of biopolitics. In this light, a 
genealogy of the geographical concept of environment, for example, would be concerned with how the term came to be bound up with a vast range of governmental and political projects today. In this context, it is fruitful to make a comparison between the canon of political thought, as it has been progressively expanded by Skinner, Geuss and others, and the scope of a genealogy of geographical concepts. It is worth noting that despite its expansion, the Cambridge Texts in the History of Political Thought have little to say about the history of key geographical concepts, including nature and environment, reflecting the marginality of discussions of the politics of nature to mainstream political theory. ${ }^{43} \mathrm{By}$ contrast, while not necessarily drawing on Foucault's work explicitly, geographers have increasingly interrogated the way in which the nature has come to be framed as a domain external to politics yet, at the same time, as the object of a series of economic and political interventions over time. As Hinchliffe, Degan, Kearnes and Whatmore observe, the idea of nature has often been deployed as an anti-political instrument, serving to restrict the potential for political disagreement: 'nature as distant land, or as an outside to human affairs, has been called up, and called upon, as a stop to all manner of debate and struggle, often with disastrous effects. ${ }^{.44}$ In this political situation, in which the concept of 'nature' is routinely deployed as an element of an anti-politics, there is a need to unravel the naturalness of nature through genealogical inquiry. ${ }^{45}$ Likewise, for Elden, the genealogy of territory is politically relevant because, in the context of the 'war on terror' and the aftermath of the break-up of the Soviet Union, the stability of territorial boundaries is in question. ${ }^{46}$ Rather than assume that the concept of territory is necessarily coupled to ideas of the nation-state or sovereignty, there is a need to interrogate the variability of the concept of territory, and its politics. One reason why a genealogy of geographical thought is relevant today is because of the continuing centrality of geographical concepts, including territory, nature and environment, to political life.

If Foucault's genealogy directs us to consider both the political history of concepts and the importance of concepts to contemporary politics, the work of Isabelle Stengers is intended to perform a different kind of intervention, based on the idea of anamnesis. Moreover, while Foucault's work addresses the entanglement of knowledge production and governmentality, Stengers asks us to consider the politics of the relations between different forms of knowledge production, or what she terms 'ecologies of practice'. Whereas Foucault directs us to consider the genealogy of concepts, Stengers' anamnesis of the physical sciences, I suggest, challenges dominant accounts of the relations between 
the sciences, while also enabling us to rethink the relation between geography and other disciplines, as well as the geographical practice of non-experts. In so doing, Stengers' work also serves to expand the scope of the geographical canon and demonstrate its political relevance.

\section{Anamnesis and the hierarchy of the disciplines}

In her seven-volume study in the history and philosophy of the sciences, Cosmopolitics, Stengers argues that anamnesis, 'defined as the voluntary evocation of the past', needs to be clearly distinguished from what she takes to be Foucault's archaeological method: 'it is not a matter of bringing to light forgotten strata. ${ }^{47}$ Nor does Stengers' approach to the history of science reflect the work of sociologically minded historians of science. She does not, for example, draw inspiration from Steven Shapin and Simon Schaffer's interrogation of the dynamics of the controversy between the natural philosopher Robert Boyle and the political philosopher Thomas Hobbes over the possibility of an experimental demonstration of the existence of a vacuum - a study that powerfully informed Bruno Latour's examination of the 'modern' purification of science and politics. ${ }^{48}$ Contrasting her approach with both Foucault's and the sociologists', Stengers contends that we should return to reading texts that are far from being obscure, unreadable or repressed. In effect, the practice of anamnesis is intended to give renewed value to certain well-known scientific texts:

For, if the past has been forgotten, there has been no disguise but rather the intent - then the habit - to forget. This is shown by the fact that the texts to which we should return remain perfectly readable, and we could say that their readability is disturbing.....The questions asked by these texts have not been suppressed in such a way that they would be repeated involuntarily, nor have they been cancelled by a conquering knowledge that would drain them of meaning. It's as if there had been a "decision" to turn our backs on them, a decision to withdraw from the obligations to make them explicit. ${ }^{49}$

In asking us to read texts whose value has been neglected, she deliberately decouples her interpretation of texts from the analysis of their wider political and economic context. Indeed, in Cosmopolitics she writes as a philosopher, who wants to intervene in the practice 
of science, rather than understand the earlier work of scientists as the product of what sociologists and historians have typically understood as external 'social' conditions. In doing so, Stengers echoes the work of the philosopher A.N. Whitehead who, in Science and the Modern World, highlighted the importance of romanticism as well as quantum mechanics and relativity theory to an understanding of the reality of the physical world, but was uninterested in the question of the relation between the physical sciences and the development of industrial capitalism and empire in the late nineteenth and early twentieth centuries. ${ }^{50}$

Nonetheless, although Stengers is not concerned with what is conventionally understood to be politics, her intervention in the history of science is an explicitly political one; it is even, as she puts it, 'imprinted with a certain violence. ${ }^{51}$ Anamnesis implies the need to re-establish, in her view, the 'obligations whose deliberate rejection becomes - based on this reading - part of the identity of twentieth century physics. ${ }^{52}$ She wants to restore the intellectual value of work that is widely known, but no longer read. ${ }^{53}$ It is in this light that we can understand her blunt assertion that 'there are no neutral narratives [of the history of science]. ${ }^{54}$ If the idea of the canon necessarily implies that some texts should be valued more than others, then Stengers is centrally concerned with the question of what texts in the history of the physical sciences should be valued and deserve to be re-read, in order to animate our thinking in the present.

In this part of this paper I want to draw out two elements of Stengers' argument in Cosmopolitics relevant to the concerns of geographers, which suggest how it might be possible to transform and expand the scope of the geographical canon, as well as the canon of the physical sciences. First, Stengers contests the idea that there is, or should be, a hierarchical relation between the discipline of physics, in so far as it is thought to be concerned with the study of general laws and principles, and disciplines such as chemistry and metallurgy that are considered to be more applied, or oriented more towards specific problems, situations, and environments. ${ }^{55}$ Secondly, and relatedly, Stengers gives value both to the field sciences and what she terms 'ecologies of practice' that exist beyond the boundaries of the academy. ${ }^{56}$ If Foucault's genealogies have helped to interrogate the distinction between geography and politics, Stengers' anamnesis both challenges the hierarchy of the disciplines, and the distinction between disciplinary and lay expertise. In what follows, I first discuss Stengers' account of anamnesis before 
addressing its implications for the debate about the constitution of an expanded geographical canon.

In the preface to Cosmopolitics, Stengers opens with the question: 'how can we examine the discordant landscape of knowledge derived from modern science? ${ }^{57}$ One common answer to this question, which Stengers clearly wants to reject, is the idea that the differences and apparently 'mutually exclusive visions' of different sciences are all, in the end, reducible to the fundamental laws of physics. For Stengers, the strength of the belief in this idea, and what she had earlier termed its 'virulence', has become a problem: physicists come to view themselves as the only scientists capable of addressing fundamental questions. ${ }^{58}$ However, knowledge cannot be unified by an appeal to the regulative ideal of the fundamental laws of physics she argues, for 'no unifying body of knowledge will ever demonstrate that the neutrino of physics can coexist with the multiple worlds mobilized by ethnopsychiatry. ${ }^{, 59}$

Indeed, at the heart of Stengers' counter to the dominance of a certain vision of physics, as the repository of 'fundamental laws', is a focus on some of the foundational texts of nineteenth-century thermodynamics, including the work of Sadi Carnot, Rudolf Clausius and the chemist and philosopher Pierre Duhem. Stengers' argument is that the development of twentieth-century physics blunted the intellectual challenge of thermodynamic theory by suggesting that its conclusions could be understood as statistical effects, ultimately reducible to the aggregate motion of large numbers of individual atoms and molecules. In this way, thermodynamics came to be regarded merely as a standard toolkit that could be deployed when necessary and taught to undergraduates, but was no longer of any theoretical or conceptual interest. ${ }^{60}$

Stengers has nothing explicit to say about the history of geography in Cosmopolitics, and her concerns for thermodynamics may initially seem far removed from the interests of most geographers. Nonetheless, she has no difficulty with the problem of 'physics envy' that has sometimes blighted the development of the discipline of geography. ${ }^{61}$ On the contrary, she seeks to give a new sense of value to those ecologies of practice that address the contingency, path-dependency and complexity of the world outside of the purified domain of the laboratory. It is in this context that she stresses the value of the 
'field sciences', recognising that there is necessary tension between the specificity of the field and the simplifications of the model:

....in the theoretical-experimental sciences [a model] has a domain of validity that is carefully delimited, for, through its definitions, it employs simplifying expedients whose scope is explicitly relative to this domain... Once it is a question of the field sciences, however, the model is no longer defined by its simplification or by ad hoc hypotheses. It no longer belongs to a practice designed to 'prove', because the validity of a given proof would, in any event, be valid only for a given situation. Rather, it is a question of producing a problematic tension between what the model requires and what the field discloses. ${ }^{62}$

Rather than assume that experiment is necessarily central to the practice of science, Stengers directs us to consider the specific value of field research and its relation to other forms of research practice, including modelling and experiment. The complexity of the situation in the field is unlikely to be able to be exhaustively modelled, as she observes, but the relation between the specificity of the field and what the 'model requires' may be generative nonetheless.

In theorising the production of knowledge, Stengers conceives of herself as a constructivist. In other words, she views the production of knowledge as a creative practice that is generative of new entities. In Cosmopolitics, in particular, she highlights the vital role of measurements of temperature and pressure in the constitution of the thermodynamic system. The scientific observer, for Stengers, is not a naïve empiricist who mistakenly believes that phenomena are simply waiting to be observed. Neither is she a social constructivist, who is indifferent to the constraints that the world should place on its interpretation. On the one hand, in her account, researchers interact with and participate in the world that they observe, in part through practices of measurement. ${ }^{63}$ On the other hand, scientific analysis necessarily involves abstraction; yet abstractions are never merely human constructs: 'abstraction expresses nature's mode of interaction and is not merely mental. When it abstracts, thought is merely conforming to nature. ${ }^{.64}$ In this context, the challenge for the researcher is to recognise the difference between those 
abstractions that are potentially generative and those that are merely empty generalisations and that should therefore be abandoned.

\section{$\underline{\text { Stengers' geography }}$}

What is the relevance of Stengers' history and philosophy of the physical sciences to the concerns of geographers, and how does her work open up the possibility of a more expansive sense of the geographical canon? To be sure, geographers have understood the discipline in ways that Stengers would, no doubt, find problematic. Some academic geographers have thought that it would be possible, eventually perhaps, to establish geography as a 'general and unifying discourse' that integrates the various fields of the social and natural sciences. ${ }^{65}$ And certain geographers have thought it might be possible to derive scientific spatial laws, and offer spatial explanations. In short, geography has sometimes to be modelled on a version of physics, and a conception of the hierarchy of the disciplines, that Stengers wishes to contest. Nonetheless, while she is certainly not opposed to scientific generalisation per se, her philosophy echoes the work of geographers who, in diverse ways, have long argued that the specificity of the place or situation matters, and that one should not imagine that the complexity of concrete realities can be explained by reference to general laws. Indeed, although she is not a proponent of complexity theory per se, Stengers argues that the idea of complexity is valuable in so far as it calls into question the possibility of 'a general and unifying discourse. ${ }^{.66}$

Certainly, the history of geography is marked by the wealth of attempts to give due attention to the importance of specificity and the variability of phenomena, recognising the need, as Alexander von Humboldt once observed, to 'analyse the parts of natural phenomena without succumbing to the weight of the whole. ${ }^{67}$ The longstanding preoccupation of geographers with the idea of the region, and the possibility of a discipline devoted to the study of local and regional environments, can be understood in this context. In P. Vidal de la Blache's formulation, for example, 'the geographical task lay in the investigation of how, in particular places, a variety of natural realms provide the milieu in which human life styles were shaped. ${ }^{68}$ For Hilda Ormsby, 'The geographer with his training in regional studies can perhaps best present to those experts in social welfare the picture of a unit area made up of a multitude of interacting forces.' ${ }^{69}$ 
It is commonplace to regard regionalism as largely of historical or scholastic interest. Indeed, the idea that one could examine the natural and human elements of a region as an integrated whole appears to have largely been abandoned, although there are some signs of its resurgence. ${ }^{70}$ But one might equally suggest that regionalism directs us to a problem that resonates with the challenge that thermodynamics poses, as Stengers contends, to a certain vision of scientific research. Geographers, like chemists, have tended to insist on the problem of specificity and variability, even if they have disagreed both on how to conceptualise variability and on how to account for it. In response, the history of geographical thought has produced a series of concepts - territory, environment, area, border, continent, place, as well as region - that try to capture that variability, by grounding it in analysis of what A.J and F.D. Herbertson once termed its 'major units. ${ }^{71}$

And yet geographers have increasingly questioned the idea that variation should be understood in terms of a series of discrete units with clear identities and distinct boundaries. ${ }^{72}$ Indeed, variation has increasingly come to be understood as a dynamic process, rather than simply an effect or product. Seen in these terms, a history of approaches to the geographical problem of variation might legitimately include the work of authors who did not identify themselves as geographers at all. Rosa Luxemburg, for example, provided an analysis of the dynamic relation between capitalism and non capitalist modes of production; ${ }^{73}$ Antonio Gramsci highlighted the contingent political interference of historical tendencies; ${ }^{74}$ and Frantz Fanon emphasised the significance of the psychological as well as the tactical dynamics of the Algerian revolution. ${ }^{75}$ In the same way, while Stengers herself routinely talks about chemistry, she does not equate chemical thought narrowly with the work of identifiable chemists. Indeed, two of the key figures in Cosmopolitics, Carnot and Clausius, were not strictly chemists at all. In her reading, however, these authors articulate ways of thinking that have been, and should be, characteristic of chemistry. Likewise, Stengers' work suggests that if, following Geuss and Skinner, we were to construct a series of texts in the History of Geographical Thought this should include the work of those who would not ordinarily be counted as geographers.

While Stengers emphasises the importance of the practice of measurement to the physical sciences, she equally wishes to give value to experiences and practices that do 
not use measurement at all. In this respect, her work has parallels with recent developments in geographical theory, in recognising that an account of an event should never, in principle, be defined by practices of measurement, but should include the full range of forms of experience, which might potentially include, for example, anger, concern or revulsion, as well the immediacy of affective response. For Stengers it would be fruitless to try to provide an 'integrated' or unified account of such discordant experiences, but it is nonetheless essential to address their mutual coexistence or, as she puts it, 'their problematic copresence. ${ }^{76}$ At the same time, the geographer should acknowledge the 'diversity of knowledge practices', the multiple forms of construction that will never be unified, but nonetheless may be brought together, as Sarah Whatmore suggests, in the form of contingent 'working alliances' that may disturb and go beyond the boundaries of established scientific disciplines. ${ }^{77}$

In this light, and in the context of Stengers' philosophy, one of the virtues of geographical thought is that geographers have tended to insist on the need to address the mutual coexistence of diverse forms of experience. An anamnesis of geographical thought, following Stengers, would equally highlight the way that geographers have sought in diverse ways to address the complexity of experience. For Franz Boas, for example, geographers had to develop an 'affective' as well as an 'aesthetic' relation to their subject matter. ${ }^{78}$ And Halford Mackinder once proposed that the rational study of political geography 'should be built upon and subsequent to physical geography. ${ }^{, 79}$ Although this project is now regarded as misconceived, the question of the relation between different forms of experience and different modes of natural and social scientific inquiry has continued to be posed throughout the history of geography. Indeed, the history of geographical thought has been marked by attempts to think across, and not necessarily to unify, as Stengers would put it, the 'discordant landscape' of knowledge. Against this background, the concerns of earlier geographers with the question of the relation between different modes of inquiry deserve to be re-read. ${ }^{80}$ Stengers does not direct us towards the status of canonical authors; rather she asks us to transform our sense of the range of texts and practices that should be valued.

\section{Conclusion: For an expanded canon and a contested tradition}

One can understand why the idea of a canon no longer seems to be appealing to many 
geographers. The apparent authority of canonical texts has served to regulate what counts as disciplinary inquiry and to police disciplinary boundaries, as Skinner and others once argued in relation to the discipline of politics. In particular, the desire of geographers such as 'Sauer, Hartshorne, and others to secure authority through the citation of textual pedigree is part of the larger process by which geography's disciplinary identity has been forged and its methodological agenda defined. ${ }^{81}$ According to their critics, the defenders of the canon can come to be preoccupied with the historical identity of a discipline at the expense of its future evolution. As Skinner suggested, a canon can readily define 'the timeless essence' of a discipline and, in doing so, merely serve to 'discipline disciples. ${ }^{, 82}$ In these circumstances, the proper task of the historian is a critical one: to reinterpret what were once thought of as canonical texts in their historical context.

Yet despite the force of this broad line of argument, my contention is that the idea of a geographical canon should be valued, and indeed could be given renewed value. A canon need not and should not define the 'timeless essence' of a discipline for, as historians tell us, disciplines never have timeless essences or clear and distinct boundaries. All disciplines are, in some way, interdisciplinary. ${ }^{83}$ In these circumstances, the components of any proposed canon are not fixed nor confined to the works of geographers, and they are likely to be, and should be, contested. Although a preoccupation with the authority and constitution of the canon is likely to be detrimental to the life of a discipline, the existence of a lively debate over the contents and contours of the canon can nonetheless be generative. ${ }^{84}$

In developing this argument, Foucault's notion of genealogy and Stengers' account of anamnesis are both suggestive. Genealogy directs us towards the history of geographical concepts and, in doing so, raises questions about the contingency of their origins, the multiplicity of their lines of movement, and their entanglement with the exercise of domination and government. By interrogating the constitution of key geographical concepts, the genealogist opens up the question of the politics of geographical thought, and its potential for change. The philosopher and co-editor of the Cambridge Texts on the History of Political Thought, Raymond Geuss, rightly criticises the tendency of political philosophers to preoccupy themselves with the interpretation of canonical texts at the expense of any concern with what he terms 'real politics. ${ }^{95}$ And as Elden observes, a 
genealogy of the concept of territory, for example, can and should inform how we think about the politics of territory today ${ }^{86}$ For the genealogist, geographical concepts are not just to be found in the writings of geographers. At the same time, the development of an expanded geographical canon cannot and should not be decoupled from an engagement with contemporary politics.

In contrast to genealogy, but perfectly compatible with it, the practice of anamnesis is intended to give renewed value to texts and authors who may be widely known, but are no longer widely read. Stengers invites us to re-read texts that should continue to raise questions and offer provocations that can animate our thinking in the present. In this light, it is striking that at the heart of her interest lies the way that historical texts can help to challenge a dominant vision of the hierarchical order of the disciplines. In this endeavour, she gives value to those 'ecologies of practice' that recognise the importance of fieldwork, that address the need to account for the existence and process of variation, and that give value to a diverse range of practices of knowledge production, including by non-experts. If the canon is often thought to be the repository of the most 'universal ideas', Stengers calls on us to consider the critical value of ideas and practices that are anything but universal. In this way, her anamnesis of the physical sciences is of particular relevance to those concerned with the politics of geographical practice.

There are good reasons for questioning and rejecting the idea of the canon, and they should not be forgotten. It is a mistake to imagine that the discipline has or should have an incontestable essence that can be found in a small number of canonical texts, and the constitution of the canon has historically been associated with more or less systematic forms of exclusion, and the reduction of challenges to doxa. However, the regulative authority of the geographical canon has arguably become limited, or even ignored altogether. In these circumstances, it is possible to reinvent the idea of the canon and to expand its scope. The construction of such an expanded canon is much more than a matter of incorporating a substantial range of lesser-known works. The challenge is to show why reading particular historical texts should continue to matter. An expanded canon should not function as a new regulative authority, but open up new possibilities for thinking politically in the present. 
${ }^{1}$ Q. Skinner, Meaning and understanding in the history of ideas, in Visions of Politics volume 1: Regarding Method, Cambridge, 2002, 57-89 (original publication: History and Theory 8 [1969] 3-53).

2 Skinner, Meaning and understanding in the history of ideas, 79; R.G. Collingwood, The Idea of History, Oxford, 1946, 283. Robert Mayhew argued that this approach had particular relevance for the history of Geography see R. Mayhew, Contextualizing practice in intellectual history, Journal of Historical Geography 20 (1994) 323-328.

${ }^{3}$ Skinner, Meaning and understanding the history of ideas, 83.

${ }^{4}$ Collingwood, The Idea of History, cited in P. Burke, Context in context, Common Knowledge, 8, 1, 2002, 162.

${ }^{5}$ See, in particular, the paper by I. Keighren, C. Abrahamsson and V. della Dora, On canonical geographies, Dialogues in Human Geography 2 (2012) 296-312 and the responses to this paper by Hubbard, Maddrell, Mayhew, Monk, Powell, Schein, and Withers.

${ }^{6}$ C. Withers, 'Geography's evolving traditions and textual critique', Dialogues in Human Geography 2 (2012) 318

${ }^{7}$ D. Livingstone, The Geographical Tradition, Oxford, 1992, 3

${ }^{8}$ D. Matless, Effects of History, Transactions of the Institute of British Geographers 20 (1995), 407. See also R. Mayhew, Geography's genealogies, in J. Agnew and D. Livingstone (eds.) The Sage Handbook of Geographical Knowledge, London, 2011, 21-38.

${ }^{9}$ M. Foucault, Questions of Method, in Power: Essential Works 1954-84, London, 2002, 230.

${ }^{10}$ Cambridge Texts in the History of Political Thought,

http://www.cambridge.org/aus/series/sSeries.asp?code=CTPT (last accessed, January 2014), emphasis added.

${ }^{11}$ P. Koikkalainen and S. Syrjämäki, On encountering the past - an interview with Quentin Skinner, http://www.jyu.fi/yhtfil/redescriptions/Yearbook\%202002/Skinner Interview 2002.pdf

${ }_{12}$ R. Mayhew, Enlightenment Geography: the Political Languages of British Geography 1650-1850, Basingstoke, 2010, 11. See also, R. Mayhew, Contextualizing practice in intellectual history.

${ }^{13}$ Withers, Geography's evolving traditions and textual critique, 317.

${ }^{14}$ D. Livingstone, The Geographical Tradition, 3.

${ }^{15}$ H-G. Gadamer, Truth and Method, London, 1989 [1960], 277.

${ }^{16}$ R. Mayhew, On canons, cannons and the rapier', Dialogues in Human Geography, 2, 2012, 314.

${ }^{17} \mathrm{~F}$. Driver, Research in historical geography and in the history and philosophy of geography in the UK, 2001-2011: an overview, Journal of Historical Geography, 42, 2013, 203-211. See also, F. Driver, Geographical traditions: rethinking the history of geography, Transactions of the Institute of British Geographers, NS, 20 (4), 403-404.

${ }^{18}$ cf P. Hubbard, The return of the living dead, Dialogues in Human Geography, 2(3), 2012, 332-334

${ }^{19} \mathrm{C}$. Barnett, Awakening the dead: who needs the history of geography? Transactions of the Institute of British Geographers 20 (1995) 417-419.

${ }^{20}$ See, for example, M. Bassin, Imperialism and the nation State in Friedrich Ratzel's political geography, Progress in Human Geography 11 (1987) 473-495. On the relations between sociology and empire see A.

Toscano, Empires of pacification: state and empire in Gabriel Tarde, Economy and Society 36 (2007) 597613; cf Agnew, On canons and fanons, 322; C. Barnett, Awakening the dead: who needs the history of geography?, 418. On the relations between the history of geography and the history of anthropology see Powell, this volume.

${ }^{21}$ A. Maddrell, Treasuring classic texts, engagement and the gender gap in the geographical canon, Dialogues in Human Geography 2 (2012) 325; J. Monk, Women, gender, and the histories of American geography, Annals of the Association of American Geographers 94 (2004) 1-22; A. Maddrell, Complex Locations: Women's Geographical Work in the UK, Chichester, 2009.

22 Agnew, Canons and fanons.

${ }^{23}$ R. Johnston, Geography - coming apart at the seams, in N. Castree, A. Rogers and D. Sherman (eds.), Questioning Geography: Fundamental Debates, Oxford, 2005, 9-25. 
${ }^{24}$ Hubbard, The return of the living dead.

${ }^{25}$ F. Driver, Geography Militant: Cultures of Exploration and Empire, Oxford, 2001; R. Powell, Geographies of science: histories, localities, practices, futures, Progress in Human Geography 31 (2007) 309-329.

${ }^{26}$ P. Kropotkin, The Conquest of Bread and Other Writings, Cambridge, 1995.

${ }^{27}$ M. Foucault, Discipline and Punish, London, 1977, 200-209;

${ }^{28}$ Foucault, Questions of Method, 230.

${ }^{29}$ S. Elden, The Birth of Territory, Chicago, 2013, 8.

${ }^{30}$ e.g. R. Geuss, Outside Ethics, Princeton, 2005.

${ }^{31}$ M. Foucault, Nietzsche, genealogy, history, in P. Rabinow (ed.) The Foucault Reader, London, 1986, 82.

32 T. Osborne, The Structure of Modern Cultural Theory, Manchester, 2008, 100; see also M. Foucault, Questions of method, 226-227; R. Mayhew, Geographies genealogies, in J. Agnew and D. Livingstone (eds.) The Sage Handbook of Geographical Knowledge, London, 2011, 28-29.

33 There is, of course, a much larger body of literature on Foucault's lectures, in geography and other disciplines. For a survey and a significant recent contribution see C. Philo, A 'new Foucault' with lively implications - or 'the crawfish advances sideways', Transactions of the Institute of British Geographers 37 (2012) 496-514. For a wider range of geographical readings of Foucault see J. Crampton and S. Elden (eds.) Space, Knowledge and Power: Foucault and Geography, Farnham, 2007.

${ }^{34}$ S. Elden, Governmentality, calculation, territory, Environment and Planning D 25 (2007) 562-580; S. Elden, How should we do the history of territory?, Territory, Politics, Governance 1 (2013) 5-20.

${ }_{35}$ M. Foucault, Security, Territory, Population: Lectures at the College de France, Basingstoke, 2007, 296, 308.

${ }^{36}$ Elden, The Birth of Territory, 321.

${ }^{37}$ P. Riley, Introduction to G. Leibniz, Political Writings, Cambridge, 1988.

${ }^{38}$ Driver, Research in historical geography, 205.

${ }^{39} \mathrm{~T}$. Osborne and N. Rose, In the name of society: or three theses on the history of social thought, History of the Human Sciences 10 (1997) 87-104.

${ }^{40}$ Livingstone, The Geographical Tradition, chapter 6; R. Powell, Echoes of the new geography? History and Philosophy of Geography I, Progress in Human Geography 36 (2012) 521-522.

${ }^{41}$ S. Legg (ed.), Spatiality, Sovereignty and Carl Schmitt: Geographies of the Nomos, London, 2011; S. Elden and E. Mendieta (eds.) Reading Kant's Geography, New York, 2011.

${ }^{42}$ Elden, The Birth of Territory, 2; M. Foucault, Discipline and Punish, London, 1977.

${ }^{43}$ J. Bennett, Vibrant Matter: a Political Ecology of Things, Durham, NC, 2010; A. Brett, Changes of State: Nature and the Limits of the City in Early Modern Natural Law, Princeton, 2011; B. Braun and S. Whatmore (eds.), Political Matter, Minneapolis, 2010; cf R.G. Collingwood, The Idea of Nature, Oxford, 1945

${ }^{44}$ S. Hinchliffe, M. Degen, M. Kearnes and S. Whatmore, Urban wild things: a cosmopolitical experiment, Environment and Planning D 23 (2005) 643.

${ }^{45}$ On the idea of a political situation see A. Barry, Material Politics: Disputes along the Pipeline, Chichester, 2013.

${ }^{46}$ Elden, The Birth of Territory, 18.

${ }^{47}$ Stengers, Cosmopolitics I, 182.

${ }^{48}$ S. Shapin and S. Schaffer, Leviathan and the Air-Pump: Hobbes, Boyle and the Experimental Life, Princeton, 1985; B. Latour, We Have Never Benn Modern, Hemel Hempstead, 1993.

${ }^{49}$ Stengers, Cosmopolitics I, 182.

${ }^{50}$ A.N.Whitehead, Science and the Modern World, Cambridge, 1926.

51 Stengers, Cosmopolitics I, 182.

52 Stengers, Cosmopolitics I, 182.

${ }^{53}$ Powell, Echoes of the new geography? History and Philosophy of Geography I, 519.

${ }^{54}$ Stengers, Cosmopolitics I, 189, see also 130.

55 I. Stengers, Cosmopolitics II, Minneapolis, 2011, Barry, Material Politics, chapter 7.

${ }^{56}$ Stengers contrasts the transcendent vision of physics with the idea of an 'ecology of practices', which is always situated in its surroundings: "With the surroundings" would mean that no theory gives you the power to disentangle something from its particular surroundings, that is, to go beyond the particular towards something we would be able to recognise and grasp in spite of particular appearances', I. Stengers, Introductory notes on an ecology of practices, Cultural Studies Review 11 (2005) 183-196; see also S.

Hinchliffe, M. Degen, M. Kearnes and S. Whatmore, Urban wild things: a cosmopolitical experiment, 643658.

${ }^{57}$ Stengers, Cosmopolitics I, vii, emphasis added.

58 I. Stengers. Power and Invention, Minneapolis, 1997, 22; Stengers, Cosmopolitics I, 235. In this context, there are evident resonances between Stengers' approach, which are beyond the scope of this paper, and the work of Donna Haraway, Simians, Cyborgs, and Women, London, 1991.

${ }^{59}$ Stengers, Cosmopolitics I, vii. 
${ }^{60}$ A. Barry, Thermodynamics, Matter, Politics, forthcoming in Distinktion: Scandinavian Journal of Social Theory (2015).

${ }^{61} \mathrm{D}$. Massey, Space-time, 'science' and the relationship between physical geography and human geography, Transactions of the Institute of British Geographers 24 (1999) 261-276.

${ }^{62}$ Stengers, Cosmopolitics II, 273.

${ }^{63}$ I. Hacking, Representing and Intervening, Cambridge, 1983.

${ }^{64}$ A. N. Whitehead, Symbolism: its Meaning and Effects, Cambridge, 1927, 25-26; M. Halewood, A.N.

Whitehead and Social Theory, London, 2011, 147-148.

${ }^{65}$ G. Weszkalnys and A. Barry, Multiple environments, useful science, in A. Barry and G. Born (eds.) Interdisciplinarity: Reconfigurations of the Social and Natural Sciences, London, 2013, 178-208.

${ }^{66}$ Stengers, Power and Invention, 5.

${ }^{67}$ A. von Humboldt, Cosmos: a Sketch of the Physical Description of the Universe, Baltimore, 1997, 24.

${ }^{68}$ P. Vidal de la Blache, Principles of Human Geography, London, 1926, 267.

${ }^{69}$ H. Ormsby, Regional Survey in a large City, Geography 14 (1) (1927), 45, cited in A. Maddrell, Revisiting the Region: 'ordinary' and 'exceptional' regions in the work of Hilda Ormsby, 1917-1940, Environment and Planning A 38 (2006) 1739-52.

${ }^{70}$ This resurgence is particularly marked in the field of Arctic System Studies, Richard Powell, personal communication, 2014.

${ }^{71}$ A.J. Herbertson and F.D Herbertson, Man and His Work: an Introduction to Human Geography, London, 1899.

${ }^{72}$ A. Amin, Regions unbound: towards a new politics of place, Geografiska annaler : series B, human geography, 86 (2004) 33-44; D. Massey, For Space, London, 2005.

${ }^{73}$ R. Luxemburg, The Accumulation of Capital, London, 1951, chapter 30.

${ }^{74}$ A. Gramsci, The Revolution against Capital, in Pre-Prison Writings, Cambridge, 1994, 39-42.

${ }^{75}$ F. Fanon, A Dying Colonialism, New York, 1965.

${ }^{76}$ Stengers, Cosmopolitics II, 372.

${ }^{77}$ Stengers, Cosmopolitics II, 248; S. Whatmore, Earthly powers and affective environments: an ontological politics of flood risk, Theory, Culture and Society 30 (2013) 33-50.

${ }^{78}$ Boas equates the 'aesthetic' with a scientific approach to geographical inquiry. F. Boas, The study of Geography Science 9 1887, 137-141; R. Powell, Questions on the canon?, Dialogues in Human Geography 2 (2012) 338-340; R. Powell, this volume.

${ }^{79}$ H. Mackinder, The scope and methods of geography, Proceedings of the Royal Geographical Society 9 (1887), in Democratic Ideals and Reality, New York, 1962, 214.

${ }^{80}$ R. Powell, Echoes of the new Geography?; A. Barry, Material Politics, chapter 2.

${ }^{81}$ Keighren et al, On canonical histories, 302; R. Mayhew, The effacement of early modern geography (c. 1600-1850): a historiographical essay, Progress in Human Geography 25 (2001), 390-391; Mayhew,

Geography's genealogies, 2011.

82 S. Schaffer, How disciplines look, in Barry and Born, Interdisciplinarity, 57-81.

${ }^{83} \mathrm{~A}$. Barry and G. Born, Interdisciplinarity: reconfigurations of the social and natural sciences, in Barry and Born, Interdisciplinarity, 7; T. Osborne, Inter that discipline!, in Barry and Born, Interdisciplinarity. 82.

${ }^{84} \mathrm{~F}$. Nietzsche, On the uses and disadvantages of history for life, in Untimely Meditations, Cambridge, 1997.

${ }^{85}$ R. Geuss, Philosophy and Real Politics, Princeton, 2008.

${ }^{86}$ Elden, How we should do the history of territory. 